\section{Embarking on biochemistry}

WhEN, until recently, 1 lectured to large groups of science or medical students embarking on a course of biochemistry, I took along to the first lecture about 15 different texts. I tried to explain the merits of the various books in terms of the widely varying attitudes of the students. After the lecture many students would stand perplexed and some would even express their feelings to plead that they be told what to buy. 1 understood their viewpoint but I think, as teachers, we must resist the students' plea. The truth is, of course, that biochemistry is blessed with a wealth of excellent texts and the bestbuy for any particular student is seldom an easy decision. The problem is made more difficult in the knowledge that unless a student buys a textbook by half-way through the first term he is unlikely to do so at all. In other words he has often to make his choice before he has much idea as to his interest in the subject.

The two texts under review are both excellent in their way. A. L. Lehninger's Biochemistry: The Molecular Basis of C'ell Structure and Function (Worth: New York. second edition, \$17.50) is now clearly a classic and is extremely popular with students both of science and medicine. It is also comparatively cheap in terms of length and the excellence of the printing. The Biochemistry of the Tissues (Wiley: London and New York, second edition, hardback $£ 14.50, \$ 30$; paperback $£ 6.25$. $\$ 13.50$ ) by P. Banks, W. Bartley and L. M. Birt is a more modest effort, based on their lectures to medical students at Sheffield University.

A continual problem in the teaching of biochemistry is to keep the picture of the subject as a whole before the student. Too often the older courses appeared fragmentary and the student lost the unity of the subject while they delved into the minutae of the various aspects. Lehninger keeps the story going by starting with a set of organising principles and continually referring back to them as he deals with various subjects. The story holds together very well and this is undoubtedly a main attraction for the students. The Sheffield authors had a particular group of students in mind and have tried to hold attention through a consideration of the biochemistry of the various tissues. The student has to be prepared for this approach. however, so that the earlier chapters are a somewhat skimped traditional text.

In some ways Biochemistry by $L$. Stryer (Freeman: San Francisco) has much to offer medical students. In this beautifully produced book reference is continually made to the relevance of biochemistry to medicine and physiology. Thus there is an excellent chapter on sickle-cell anaemia. Indeed there have been attempts to organise a course of biochemistry on a selection of such diseases. One thinks of Biochemistry: A Case-Oriented Approach (Mosby: Missouri) by Montgomery et al.; but again there are snags, for the student must have a proper groundwork before he is ready for this kind of treatment.

Another unifying approach that is now often used in first year courses is

\section{Biochemical tools}

Physical Biochemistry: Applications to Biochemistry and Molecular Biology. By D. Freifelder. Pp. $x+570$. (Freeman: San Francisco, 1976.) Hardcover $£ 12.40$ : softcover $£ 8.00$.

A rHOROUGiH understanding of the physicochemical tools used by the modern biochemist is essential to their intelligent use. It is unfortunately a common experience of many, if not all, teachers of physical biochemistry, however, that one of the major obstacles in the path of a diligent student is the labour necessary to wade through the often complex and seemingly endless theoretical and mathematical derivations which represent the standard approach to the subject. One solution to this dilemma is to choose a limited number of techniques and to develop fundamental equations clearly from first principles with appropriate simplifications. Such an approach is justified by the quantitative nature of many of the techniques and has been used successfully by K. F. Van Holde (also entitled Physical Biochemistry, Prentice-Hall).

An alternative and in some respects radical solution is to adopt an almost completely non-mathematical approach. Professor Freifelder has done just this with the single aim of enabling "the student to understand and read the current literature". Equations cannot be avoided, of course. hut although their derivations are, the physical principles, the assumptions behind the derivations and the conditions which must be satisfied for the equations to hold are clearly defincd. Physical Biochemistry is therefore an exceptional book in that it neither requires nor contains a knowledge of basic thermodynamics which inevitably characterises other comparable texts. For this alone many students will be thankful.

Throughout the book. Professor Freifelder's overriding concern is to to develop the biochemistry from an elementary study of cell biology. This is probably better than concentrating on the tissues. So far, however, I have not seen a textbook based on this kind of course.

In summary, both books reviewed have their strong points and certainly the latter part of the Sheffield book would prove a useful adjunct to the cheaper and much more comprehensive Lehninger text.

P. N. Campbell

P. N. Campbell is Director of the Courtauld Institute. Middlesex Hospital Medical School, London, UK.

stimulate the students' interest in the techniques of physical biochemistry. and if the avoidance of mathematical treatments is one cornerstone of his strategy, then the demonstration of the usefulness of the techniques in solving biological problems is the other. Indeed, the outstanding feature of his book is the wealth of biological examples illustrated. The majority of these are drawn from the molecular biology of bacteriophages and the physical biochemistry of DNA and viruses, reflecting Professor Freifelder's research interests and making a welcome change from the more conventional protein examples.

The subject matter is generally comprehensive, comprising an extensive section on direct observations by light and electron microscopy, general laboratory methods, separation and identification of materials. hydrodynamic methods including an especially wcllwritten chapter on sedimentation, and spectroscopic methods including a useful introduction to nuclear magnetic resonance. The qualitative approach seems nevertheless to have led to some curious omissions for a text on physical biochemistry: Thus all scattering techniques are absent. In addition there is no treatment of multiple, small molecule binding. Surprisingly, a section on immunological methods is included.

This book is properly written for final-year undergraduate and first-year graduate students. Many of them will appreciate its non-mathematical approach from which there are undoubtedly great advantages of motivation to be gained. Ultimately, however. the student who finally arrives at the practical application of a technique for his own research purpose can only benefit from a thorcugh acquaintance with the underlying theoretical and mathematical analysis. This hook will surely engender in the student sufficient enthusiasm to make the necessary effort. $\quad$ G. L. Kellett

(i. I.. Kellett is Lecturer in Biochemistry at the liniversity of York. I'K. 